\section{Daylength Influences Growth and Development of Achimenes Cultivars}

\author{
J.C. Vlahos ${ }^{1}$ \\ Department of Horticulture, Agricultural University, P.O. Box 30, 6700 \\ AA, Wageningen, The Netherlands
}

Additional index words. flowering, rhizomes, short day, long day

\begin{abstract}
Six cultivars of Achimenes, 'Blau Import', 'Blauer Planet', 'Linda', 'Prima Donna', 'Schneewittchen', and 'Tetraelfe', were grown for 16 weeks under short (SD, 8 hours) or long days (LD, 16 hours) at 21C in a greenhouse. LD increased plant height, shoot mass, number of flowers, and accelerated time to anthesis. SD, depending on the cultivar, increased number of rhizomes. Results show differences in several characteristics of growth and development among the cultivars and that LD promote shoot growth and flowering.
\end{abstract}

Achimenes (Gesneriaceae) is indigenous from Mexico to Brazil. Many cultivars have been introduced as products of hybridization and mutation breeding, both in the United States and in Europe (Broertjes, 1972). Rohde (1974) showed that flower initiation in 'Valse bleu' and 'Domröschen' does not depend on photoperiod and that flower development is not affected by daylength. Zimmer (1976), working with 'Valse bleu', 'Menuett', 'Tarantella', and 'Fritz Michelssen', found that daylengths of 8 and $16 \mathrm{hr}$ did not influence the formation of rhizomes, while weight of rhizomes depended on the cultivar.

The present study was aimed at evaluating the influence of short (SD) and long (LD) days on cultivars that have not been investigated to see if 1) there are any relationships between rhizome and shoot growth under the two daylengths, and 2) to determine which of the cultivars grow and flower satisfactorily under SD offering as an indication that they could grow during winter months when these plants are not usually produced. The effect of temperature and irradiance is reported in a companion paper (Vlahos, 1990).

Rhizomes of six morphologically different commercial cultivars from the achimenes collection maintained at the time by the Dept. of Horticulture in Wageningen were stored at $17 \mathrm{C}$ for 3 months and then planted in sphagnum peat in a greenhouse bench on 20 Feb. 1985. Tip cuttings taken from the sprouted rhizomes were planted in $10-\mathrm{cm}$ plastic pots (0.3-liter) with a standard potting medium ( $\mathrm{pH} 5.5$ to 5.8) consisting of 6 peat mold : 4 rough peat $(\mathrm{v} / \mathrm{v})$ and placed in a greenhouse at $21 / 18 \mathrm{C}$ (day/night) for rooting

Received for publication 28 July 1989. Publication no. 566, Dept. of Horticulture, Agricultural University Wageningen, The Netherlands. The author acknowledges support of a research fellowship from the State Scholarships Foundation of Greece. The cost of publishing this paper was defrayed in part by the payment of page charges. Under postal regulations, this paper therefore must be hereby marked advertisement solely to indicate this fact.

${ }^{1}$ Associate Professor of Botany. Current address: Dept. of Horticulture, Technological Educational Institute. Iraklion, 71500 Crete, Greece. and establishment. Plantlets were selected for uniformity and averaged $4.5 \mathrm{~cm}$ in height and had three leaf whorls (nodes). They were placed under SD and LD conditions on 15 Mar. 1985. SD were obtained using a black cloth cover from 1600 to $0800 \mathrm{HR}$. In the LD condition, the natural day was extended with the use of high-pressure sodium lamps (Philips SON/T) that provided a PAR of 48 $\mu \mathrm{mol} \cdot \mathrm{s}^{-1} \cdot \mathrm{m}^{-2}$ at plant level from 1900 until $2200 \mathrm{HR}$. Due to this extension, the plants received a $L D$ of $16 \mathrm{hr}$. Solar irridiation was recorded using a Kipp solarimeter placed near the plants. Daily counts for solar radiation in the LD treatment were calculated on a monthly basis that gave the amount of photosynthetic active radiation in $\mu \mathrm{mol} \cdot \mathrm{day}^{-1} \cdot \mathrm{m}^{-2}$; the values were 14.6, 19.4, and 19.8 for April, May, and June, respectively.

A split-plot design with four replications was used with daylength as the main plot factor. Each replication included six cultivars, with five plants from each. Cultivars were randomized within each replication.

Table 1. Main effect of SD (8 hr) and LD (16 hr) on growth, flowering, and rhizome development in six cultivars of Achimenes.

\begin{tabular}{|c|c|c|c|c|c|c|c|c|}
\hline Davlength & $\begin{array}{c}\text { Plant } \\
\text { ht } \\
(\mathrm{cm})\end{array}$ & $\begin{array}{l}\text { Inicrnode } \\
\text { Icngth } \\
(\mathrm{cm})\end{array}$ & $\begin{array}{l}\text { Shool } \\
\text { fresh w: } \\
\text { (g) }\end{array}$ & $\begin{array}{l}\text { Nodes } \\
\text { (no.) }\end{array}$ & $\begin{array}{c}\text { Axillay } \\
\text { shoots } \\
\text { (no.) }\end{array}$ & $\begin{array}{c}\text { Flowers } \\
\text { (no.) }\end{array}$ & $\begin{array}{l}\text { Days to } \\
\text { first } \\
\text { flower } \\
\text { (no.) }\end{array}$ & $\begin{array}{c}\text { Rhizome } \\
\text { dy wt } \\
\text { (mg) }\end{array}$ \\
\hline SD & 30.3 & 9 & 34 & 13 & 4 & 42 & 59 & 317 \\
\hline LD & 38.0 & 2.8 & 45 & 14 & 4 & 62 & 54 & 317 \\
\hline Significance & • & - & : & NS & NS & - & : & NS \\
\hline
\end{tabular}

${ }^{\mathrm{z}}$ Values arc means of 120 plants.

Ns ${ }^{*}$ Nonsignificant or significant at $P=0.001$.

Table 2. Effects of cultivar on growth, flowering, and rhizome development in six cultivars of Achimenes ${ }^{\mathrm{z}}$.

\begin{tabular}{|c|c|c|c|c|c|c|c|c|}
\hline Cultivar & $\begin{array}{l}\text { Plant } \\
\text { ht } \\
(\mathrm{cm})\end{array}$ & $\begin{array}{l}\text { Inicrnode } \\
\text { Iength } \\
\text { (cm) }\end{array}$ & $\begin{array}{l}\text { Shoot } \\
\text { fresh wt } \\
\text { (g) }\end{array}$ & $\begin{array}{c}\text { Nodes } \\
\text { (no.) }\end{array}$ & $\begin{array}{c}\text { Axillary } \\
\text { shoots } \\
\text { (no.) }\end{array}$ & $\begin{array}{c}\text { Flowers } \\
\text { (no.) }\end{array}$ & $\begin{array}{c}\text { Days to } \\
\text { first } \\
\text { fowcr } \\
\text { (no.) }\end{array}$ & $\begin{array}{c}\text { Rhizome } \\
\text { dry wit } \\
\text { (mg) }\end{array}$ \\
\hline Tctraclfe & 41.1 & 2.9 & 36.9 & 14 & 4 & 96 & 52 & 39 \\
\hline Blau Import & 44.4 & 3.0 & 49.4 & 15 & 3 & 98 & 33 & 1490 \\
\hline Blaucr Planer & 40.4 & 2.8 & 31.0 & 14 & 1 & 34 & 53 & None \\
\hline Schncewitlehen & 27.2 & 1.9 & 34.4 & 14 & 6 & 38 & 62 & 32 \\
\hline Prima Donna & 25.7 & 2.4 & 49.5 & 11 & 6 & 17 & 76 & 1 \\
\hline Linda & 26.0 & 2.0 & 34.0 & 13 & 4 & 30 & 62 & 25 \\
\hline$L S D_{0.1 .}$ & 1.9 & 0.009 & 3.4 & 0.7 & 0.7 & 9 & 3 & 88 \\
\hline
\end{tabular}

${ }^{\mathrm{z}}$ Values are means of 40 plants.
Those used were: 'Blau Import', 'Blauer Planet' (also known as 'Michelssens' Blau'), 'Linda', 'Schneewittchen', 'Prima Donna', and 'Tetraelfe'. They all belong to a new group of hybrids (Broertjes et al., 1983).

Plants were checked daily and the date that the first flower opened was recorded for each plant. At the end of the experiment, the following data were collected: height of the main stem, number of leaf whorls, number of axillary shoots, number of flowers on the main stem and the axillary shoots. As flowers do not abort when they are old, it was possible to record the total number of flowers that developed during the 16 weeks. Shoot growth (shoots and flowers) was removed for fresh and dry weight determination. Rhizomes were harvested, counted, and their weights recorded. Many plants had stolons emerging from the soil. These sprouting stoIons were counted to see if SD or LD treatments affected their number.

Data were evaluated by analysis of variance. Cultivar effects were analyzed using least significant difference at $P=0.05$.

Regardless of cultivar, LD increased plant height, internode length, shoot fresh weight, and total number of flowers. Number of days to first open flower decreased, whereas number of nodes, number of axillary shoots, and dry weight of rhizomes were not affected (Table 1).

There was no interaction between photoperiod and cultivar for several characteristics of growth and development. 'Blau Import' was the tallest cultivar, had more nodes, more flowers, along with 'Tetraelfe', and flowered earlier than the rest; shoot fresh weight of 'Blau Import' and 'Prima Donna' were equally high, but rhizome dry weight was highest for the former (Table 2). Fresh and dry weight per rhizome were also highest for 'Blau Import', whereas those of the other cultivars were similar to each other (data not 
Table 3. Interaction of SD (8 hr) and LD (16 hr) on number of stolons. number of rhizomes. shoot fresh weight, and rhizome dry weight in six cultivars of Achimenes grown for 16 weeks in a grcenhous e z $^{\text {. }}$

\begin{tabular}{|c|c|c|c|c|c|c|c|c|}
\hline \multirow[b]{2}{*}{ Cultivar } & \multicolumn{2}{|c|}{ Stolons (no.) } & \multicolumn{2}{|c|}{ Rhizomes (no.) } & \multicolumn{2}{|c|}{$\begin{array}{c}\text { Shoot dry wt } \\
(\mathrm{g})\end{array}$} & \multicolumn{2}{|c|}{$\begin{array}{c}\text { Rhizome fresh wt } \\
\text { (mg) }\end{array}$} \\
\hline & SD & LD & SD & LD & SD & LD & SD & LD \\
\hline Tetraclfe & 6.8 & 5.8 & 3.2 & 4.2 & 4.1 & 5.5 & 282 & 217 \\
\hline Blau Import & None & 1.3 & 12.4 & 11.8 & 5.7 & 6.7 & 5140 & 4018 \\
\hline Blauer Planet & 10.2 & 8.5 & None & Nonc & 3.3 & 4.9 & None & None \\
\hline Schneewittchen & 4.9 & 7.0 & 5.3 & 1.2 & 2.8 & 5.3 & 335 & 22 \\
\hline Prima Donna & 4.3 & 4.9 & 1.6 & 0.5 & 3.8 & 5.6 & 147 & 10 \\
\hline Linda & 7.9 & 9.0 & 4.2 & 1.7 & 3.4 & 3.8 & 255 & 65 \\
\hline LSO $_{n .05}$ & \multicolumn{2}{|c|}{1.4} & \multicolumn{2}{|c|}{1.9} & \multicolumn{2}{|c|}{0.5} & \multicolumn{2}{|c|}{424} \\
\hline
\end{tabular}

${ }^{\mathrm{z}}$ Values are means of 20 plants

shown). 'Prima Donna' had the fewest nodes. the fewest flowers, and flowered last; its rhizome dry weight was the lowest.

An interaction occurred between cultivar and photoperiod for number of stolons, number of rhizomes, shoot dry weight, and rhizome fresh weight (Table 3). Under both daylengths, 'Blau Import' had the fewest stolons and produced more rhizomes and the highest shoot dry and rhizome fresh weights. 'Blauer Planet' had the greatest number of stolons but formed no rhizomes. 'Schneewittchen' and 'Linda' had more rhizomes under SD than under LD; the other cultivars were not affected by daylength. Shoot dry weight was highest under LD In all cultivars, except in 'Linda'. SD rather than LD enhanced fresh weight of rhizomes in all cultivars; however, differences were not significant.

All cultivars flowered regardless of daylength. However, duration of daylength influenced several characteristics of growth and development. Because of the supplemental irradiance provided in the $\mathrm{LD}$, it was not possible to distinguish photoperiodic from irradiance effects.

LD increased vegetative growth expressed as height. internode length, and shoot fresh weight (Table 1). Similar results have been obtained in other species grown under LD (Boyle and Stimart, 1983; Gertsson, 1984; Janick, 1982). The increased height was due to longer internodes, as number of leaf whorls was not affected by daylength; these results are analogous to those of Piringer and Cathey (1960) with petunia. Rohde (1974) found that, as daylength increased, number of axillary shoots increased; our results do not agree with these findings and confirm our earlier work with other cultivars, which indicates that number of axillay shoots is clearly a cultivar characteristic (Vlahos, 1985).

LD increased the number of flowers, on both main and axillary shoots. As the number of flowers depends on the number of leaf whorls (Zimmer and Junker, 1985) and considering that number of leaf whorls did not increase, the higher number of flowers in LD than SD is attributed to the fact that more flowers developed per leaf whorl, possibly because dormant generative buds were induced to develop by an accumulation of assimilates produced by higher amounts of PAR provided under LD. Thus, although achimenes does not require a specific daylength for flower initiation, a longer photoperiod provides additional irradiance energy for more flower development.

Flower earliness was promoted by LD, as has been shown for other species (Maginess and Langhans, 1961; Welander, 1984); it seems likely that the number of flowers is related to plant height $(r=0.77)$ and to top dry weight $(r=70)$. Long days promote growth and thus enhance flowering, as has been reported for begonia by Fonteno and Larson (1982).

LD did not inhibit rhizome formation and development of rhizomes, contrary to what has been reported for other tuberizing species (Djurhuus, 1985; Fonreno and Larson, 1982). There was a tendency for higher rhizome fresh weight in SD, however, the difference was significant only in 'Blau Import' (Table 3). Number of rhizomes increased in SD only in 'Schneewittchen' and 'Linda'. The fact that the number of rhizomes was negatively correlated to the number of days to first open flower ( $r=0.68)$ suggests that rhizome formation begins after flower development.

Long days, by providing the amount of energy needed for assimilate production, clearly influence growth, flowering, and rhizome development in Achimenes (Table 1). However, significant differences existed among cultivars in their pattern of growth. 'Blauer Planet', despite good growth and flowering, did not form any rhizomes until the end of the experiment, suggesting that as a sink its flowers and shoots are more effective than its rhizomes. 'Prima Donna', with a high shoot weight, behaved similarly and produced the fewest rhizomes (Table 2). In contrast, 'Blau Import' produced both high shoot and rhizome weight, indicating a balanced assimilate movement.

The high number of flowers recorded for 'Tetraelfe' and 'Blau Import' could be partially attributable to the characteristic that their flowers are borne in clusters of three to nine from peduncles arising from the leaf axils instead of developing singly or doubly, as in the other cultivars.

The differences observed among the cultivars tested in this study should be considered by growers in their choice of a cultivar according to the intended purpose of production (flowering plants and/or rhizome production). Provided that dormancy-free rhizomes are available, if photoperiod and/ or light quantity are at least of the same level as in the present experiment, it would be possible to grow and flower achimenes in winter. The critical quantity of light required for a satisfactory growth and flowering control cannot be determined from the present investigation.

\section{Literature Cited}

Boyle, T.H. and D.P. Stimart. 1983. Devclopmental responses of Zinnia to photoperiod. J. Amer. Soc. Hort. Sci. 108:1053-1059.

Broertjes, C. 1972. Mutation breeding of Achimenes. Euphytica 21:48-62.

Broertjes, C., A. Pouwer, and J.F.M. Evers. 1983. Kleurenkeus in overvloed. Vakblad voor de Bloemisterij 35:34-35.

Djurhuus, R. 1985. The effect of photoperiod and temperature on growth and development of $\mathrm{Be}$ goma $\mathrm{x}$ tuberhybrida 'Karelsk Jomfru'. Scientia Hort. 27:123-131.

Fonteno, W.C. and R.A. Larson. 1982. Photoperiod and temperature effects on Nonstop tuberous begonias. HortScience 17:899-901.

Gertsson, U.E. 1984. Effect of temperature, daylength and light intensity on growth and development of Dipladenia sanderi Hemsl. 'Rosea'. Scientia Hort. 22:287-293.

Janick, J. 1982. Daylength response of dwarf pomegranate. HortScience 17:616.

Maginess, E.A. and R.W. Langhans, 1961. The effect of photoperiod and temperature on initiation and flowering of snap dragon (Antirrhinum majus var. Jackpot). J. Amer. Soc. Hort. Sci. 77:600-607.

Piringer, A.A. and H.M. Cathey. 1960. Effect of photopcriod. kind of supplemental light and temperature on the growth and flowering of $\mathrm{Pe}$ tunia plants. J. Amer. Soc. Hort. Sci. 76:649 660.

Rohde, J. 1974. Einfluss der tageslänge und temperature auf die trieb und blutenbildung der Achimenes hybriden, 'Valse Bleu' und 'Dornröschen'. Gartenbauwissenschaft. 32:135-150

Vlahos, J.C., 1985. Effects of GA, and BA on two cultivars Achimenes longiflora under two levels of irradiance. Acta Hort. 167:225-235.

Vlahos, J.C. 1990. Temperature and irradiance influence growth and development of three cultivars of Achimenes. HortScience. 25: 1597 1598

Welandcr, N.T. 1984. Influence of temperature and daylength on flowering of Aeschynanthus speciosus. Scicntia Hort. 22: 157-161.

Zimmer, K. and K. Junker, 1985. Achimenes, p. 391-392. In: A.H. Halevy (ed.). Handbook of flowering. vol. 1. CRC Press, Boca Raton, Fla.

Zimmer, K. 1976. Bildung and Lagerung von Achimenes Rhizomen. Deutscher Gartenbau 6:179-180 